\title{
Game addiction among adolescents and its' health impacts
}

\author{
Sitti Nur Djannah ${ }^{1}$, Fatwa Tentama ${ }^{2}$, Rendi Ariyanto Sinanto ${ }^{3}$ \\ ${ }^{1,3}$ Faculty of Public Health, Universitas Ahmad Dahlan, Indonesia \\ ${ }^{2}$ Faculty of Psychology, Universitas Ahmad Dahlan, Indonesia
}

\begin{tabular}{l}
\hline \hline Article Info \\
\hline Article history: \\
Received Mar 1, 2021 \\
Revised Jun 3, 2021 \\
Accepted Jun 17, 2021 \\
\hline
\end{tabular}

Keywords:

Gaming disorder

Health belief model

Health impact

Teens

\begin{abstract}
Online gaming is a self-entertaining activity and can be addictive. Game addiction has a negative impact. This study aimed to determine the health belief model of adolescent game disorders on health impacts. This study used a qualitative phenomenology method. Data obtained through semi-structured interviews. The sample consisted of six participants. The results showed that all participants felt vulnerable to disease, then overall realized the dangers of playing games such as staying up late, delaying eating, and delaying urinating. Then all participants learn about the benefits of reducing playtime and understand the importance of rest. Overall, all participants had the same obstacles, namely the invitation to make friends, boredom, free time, fun playing games, and not control themselves and the trend of electronic sports. Then an action stimulus was obtained, namely that all participants experienced changes in sleep patterns. All participants were sure and wanted to change their habits and continue to try, but it wasn't easy. Suggestions for participants to maintain health by limiting their playing hours to at least one hour a day to meet their physical needs.
\end{abstract}

This is an open access article under the CC BY-SA license.

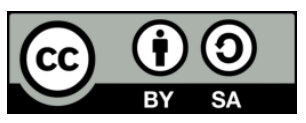

Corresponding Author:

Sitti Nur Djannah

Faculty of Public Health

Universitas Ahmad Dahlan

Prof. DR. Soepomo SH Street, Warungboto, Umbulharjo, Yogyakarta, Indonesia

Email: sitti.nurdjannah@ikm.uad.ac.id

\section{INTRODUCTION}

Now that it has entered the era of the 4.0 industrial revolution, namely industrial transformation through a combination of digital technology and the internet with conventional industries, online games are growing rapidly and are in great demand today [1]. Online games are connected via the internet and aim to make online game users feel happy and have an interest in games [2]. There are two types of individuals in playing games, some are limited to entertainment without addiction, while those who place games as a necessity or addiction, this is often referred to as a gaming disorder [3]. One of the worrying technology addiction is online game addiction, because it ultimately affects lifestyle, function, and behavior [4].

Online game addiction is a form of game use for a long time [5]. Then the main characteristic of game addiction is playing for more than three hours [6]. Regarding game addiction, the World Health Organization [7] has categorized gaming disorders as mental disorders, and this is evidenced by the many reports that discuss the topic of gaming disorders as mental disorders.

Indonesian gamers are the largest number in Southeast Asia who plays games on smartphones, personal computers and laptops, and consoles. According to data from the Indonesian Internet Service Providers Association (APJII) [8], most online gaming devices use smartphones as many as 89.9 million or around $67.8 \%$ and are predicted to increase rapidly until 2019. This is supported by the Ministry of 
Communication and Informatics's [9] estimation in 2015, which estimates that more than 100 million Indonesians will become active smartphone users in 2018.

Based on estimates, in Indonesia, about $6.1 \%$ of people addicted to games, according to the prevalence of $6.1 \%$ of game players experiencing addiction, it can be estimated that currently, there are 2.7 million game players who may be addicted [10]. In accordance with the results of observations made by researchers at one of the boarding houses on Jl. Timoho, Baciro, Gondokusuman Regency, Yogyakarta City, Yogyakarta Special Region, on July 30, 2020, it was found that teenagers had made online games a necessity of life because every day these teenagers always played games in the morning, afternoon and evening. The same thing is also found in places to eat, such as cafes and small shops, where teenagers always contact smartphones to access online games and spend their daily lives in these places with the same activities or activities, namely playing games.

Sometimes with busy playing games, the players of this game put aside basic needs, namely physical needs such as eating, drinking, delaying urinating, and not resting or sleeping. Physical needs are one of the basic needs that must be met by every individual. If basic needs are not met, it can have a negative impact on a person's health [11]. Based on the results of the interview, it was known that a teenager admitted that he often played games 2-4 hours a day, and when playing games, often delayed eating and delayed urinating because he was focused and could not leave the game.

Gamers often use smartphones to access online games so that it makes them stay up late, and there is a study that states that smartphone addiction shows poor sleep quality [12]. Poor sleep quality or lack of sleep can put you at risk of experiencing a deficiency in haemoglobin levels, and studies are showing that the effect of playing games is anaemia due to lack of sleep [13]. This can lead to heart disease due to overcompensation to the heart due to lack of rest, and this is evident from the results of research which state that people who are addicted to video games have poor health and heart disease ratings [14].

Then the health effects that arise from game addiction are changes in diet and sleep patterns that have negative impacts, such as ulcers and anaemia in-game players [15]. Not only delaying eating can be bad, but delaying drinking or not drinking water can also cause serious problems, namely the risk of dehydration or lack of fluids, resulting in unfocused, and in certain conditions, the risk of severe dehydration, which can lead to hypovolemic shock with symptoms such as dizziness, weakness, weak pulse, and decreased consciousness under certain conditions [16]. In addition, the negative impacts that will arise include physical, personal, and work or academic problems.

Currently, there are studies that discuss the impact of online game addiction on health, then on social relationships [17], [18], even on academics [19]. According to researchers at this time, there has been no research that has thoroughly discussed the personal experience of someone who is addicted to playing online games to neglect their health. In this regard, it is seen that there is a need for a health belief model to examine health beliefs in online game players. In response to this, researchers are interested in using the Health Belief Model (HBM) to change bad behaviour or habits for the better.

The Health Belief Model is a model that explains a person's judgment before behaving in a healthy manner and serves as an effort to prevent disease [20]. The Health Trust Model shows a significant relationship with behaviour change [21]. The Health Confidence Model is the most frequently used theory in health education, health promotion, and disease prevention; whereas the health belief model assumes that individuals engage in preventive behaviour when they believe there is a high likelihood of disease (perceived vulnerability), severe negative impacts. Disease (perceived severity) benefits from adopting health behaviours, and there are some barriers to health behaviours [22].

Based on the description above, the formulation of the problem in this study is how to model adolescents' health beliefs with game disorders on health impacts. The aim to be achieved is to look at models of adolescent gaming disorder beliefs on health impacts.

\section{RESEARCH METHOD}

This study used a qualitative method with a phenomenological approach, which provides an overview of the subjective experience of the health belief model of adolescent game disorders on health impacts. Then in this study, the researchers proved the Ethical Clearance from the Ahmad Dahlan University Ethics Committee with the number: 012010055.

\subsection{Research subject}

Researchers used incidental sampling techniques in this study, namely accidental sampling with certain considerations or characteristics in accordance with several inclusion criteria. The number of participants in this study was six people, while the characteristics of the participants in this study were as shown in Table 1. 
Table 1. Characteristics of participants

\begin{tabular}{cccc}
\hline Characteristics & Demographics & Frequeny & $\begin{array}{c}\text { Percentage } \\
(\%)\end{array}$ \\
\hline Gender & Man & 6 & 100.0 \\
Age & $21-24$ Years & 6 & 100.0 \\
Profession & College student & 6 & 100.0 \\
Residence & Boarding house / Rented & 6 & 100.0 \\
Early gameplay & More than six months & 6 & 100.0 \\
Long time playing the game a day & More than three hours & 6 & 100.0 \\
Addiction category & High & 6 & 100.0 \\
\hline
\end{tabular}

Source: Primary data, 2020

Based on Table 1, it can be seen that the participants in this study were six people. All of them were male and aged 21 to 24 years, then all participants were students and lived in rented houses and boarding houses. Participants in this study as a whole experienced addiction with a high category. Then have been playing games for more than six months and in a day playing games for more than three hours.

\subsection{Method of collecting data}

The data collection method used in this study was semi-structured interviews (in-depth interviews) which were designed with open-ended questions to obtain participants' views and opinions. The instrument used in this study was a human instrument with an interview guide that had expert validity first.

\subsection{Data credibility}

Data credibility is guaranteed by member checking and data triangulation. Researchers submit the results of the report to participants to check the accuracy of the information captured. Furthermore, peer checking, in the form of checking the results of interviews with supervisors through discussion. Then the triangulation used is the triangulation method by measuring the gaming addiction scale. The scale is the standard scale by Lemmens et al, modified by Bai [23]. Then the researchers modified the scale by removing neutral answer items so as not to lead the subject to neutral answers, after that the validity of the contents was returned by professional judgment, namely through the assessment of lecturers from the faculty of psychology and the faculty of public health at Ahmad Dahlan University Yogyakarta. The data from the triangulation of the gaming addiction scale is shown in Table 2. Based on Table 2, it can be seen that all participants totalled six people and experienced addiction in the high category (100\%).

Table 2. Participant addiction criteria

\begin{tabular}{cccc}
\hline No & Addiction category & Frequency & Percentage (\%) \\
\hline 1 & High & 6 & 100.0 \\
2 & Moderate & 0 & 0 \\
3 & Low & 0 & 0 \\
\hline (Source: Primary data, 2020) & &
\end{tabular}

\subsection{Data analysis}

Qualitative data analysis began by examining all available data from various sources, namely from interviews and triangulation collected. The researchers then used a phenomenological analysis, according to Creswell [24]. The steps taken in data analysis are as follows: (i) organizing the data, (ii) reading all the data, (iii) coding, (iv) developing themes and data descriptions, (v) connecting between themes, (vi) interpretation.

\section{RESULTS}

\subsection{Health Belief Model on participants}

Based on interviews with six participants, researchers obtained information that captures how to model the participants' health beliefs on the health effects of game addiction, namely that all participants feel vulnerable to experiencing pain, then know the dangers due to frequent habits, besides that all participants know the benefits of reducing playing hours. games. Furthermore, all participants had obstacles to reducing their hours playing online games, and all participants had a fear of habits that are often done now, then all participants had the confidence to seriously want to change habits, and would keep trying, even though there were some participants who did not know-how. 


\subsubsection{Susceptibility to disease}

Regarding the vulnerability to experiencing pain, all participants felt vulnerable to experiencing pain and believed in game addiction's negative effects.

"Yes, for the sick, yes, but the sickest ones were dizziness, aches, headaches, like that." (Participant $1, \mathrm{G})$

"E seems like yes." (Participant 2, S)

"Yes, my own body feels vulnerable, especially common diseases such as coughing, colds, dizziness." (Participant 3, P)

"Ee, vulnerable, if you are tired, you will be vulnerable to illness." (Participant 4, F)

"Vulnerable for sure, mas." (Participant 5, D)

"Yes, yes." (Participant 6, P)

\subsubsection{Severity/trustworthiness of negative impacts}

The severity/belief in the negative impact, namely all participants often stay up late, difficult time management, often delay eating, and heartburn. Besides that, you usually hold and delay urination, then feel dizzy, tired, and have back pain. When playing games, they often forget to eat, lack appetite, interfere with concentration, and also interfere with the need for rest. In addition to experiencing insomnia, participants also knew about the dangers of staying up late, the risks of delaying eating, and the dangers of holding back urination.

"It can also cause pain from lack of sleep, right?." (Participant 1, G)

"For example, if we delay eating, it can cause ulcers, and delaying drinking can cause dehydration." (Participant 1, G)

"Yes, we can catch infections like that." (Participant 1, G)

"I used to have dizziness, back pain." (Participant 1, G)

"I think it has a negative impact because I usually don't get enough sleep, especially during college holidays and the following holidays, so I play games from night to morning." (Participant 2, S)

"Oh yeah, especially if we are fun, we will have fun when playing games there are points, for example, the points are less than five, let's play and eat later." (Participant 2, S)

"If you postpone peeing, of course, especially when you play, we are often on the second floor, so the bathroom is downstairs, so if you want to go down lazy, especially if you are lazy to play first, let it be delayed." (Participant 2, S)

"Often bro, it's been every day." (Participant 3,P)

"I often have heartburn like that." (Participant 3, P)

"You can do this, what, have kidney stones." (Participant 3, F)

"Yes, tired." (Participant 4, F)

"It's like heartburn, usually when I play games for too long, my eyes hurt and my head hurts too." (Participant 4, F)

"Little do I know about the dangers of hearing from healthy people, it usually causes urinary tract disorders." (Participant 4, F)

"Maybe what's wrong, insomnia, dizziness, especially a lack of appetite, which I usually feel is a lack of appetite." (Participant 5, D)

"Sometimes I forget, bro, when I am playing games, for example, I have to eat right now, forget, postpone, a delay like that." (Participant 5, D)

"Maybe it can interfere with my concentration because I often play games; usually it disturbs my sleep needs too." (Participant 5, D)

"Yes, maybe later, if we do it often, there will be disturbances in our urine." (Participant 5, D)

"Yes, one of them is that we are short of blood." (Participant 6, P)

"Can cause ulcer disease." (Participant 6, P)

"Yes, you can pee stones later, right?." (Participant 6, P)

"Destroys the kidneys." (Participant 6, P)

\subsubsection{Trust benefit}

The benefit of this belief is that all participants know the benefits of reducing game hours because rest is very important to avoid disease and maintain health.

"Maybe we can reduce our habits now, so we don't get sick." (Participant 1, G) 
"Maybe for health, yes." (Participant 2, S)

"Yes, maybe to prevent worse things in the future." (Participant 3, P)

"Maybe it's just to maintain health, because if you play a lot, you can get tired too quickly." (Participant 4, F)

"If you reduce playing hours, it can be better." (Participant 5, D)

"Yes, yes, I am aware that it is not very good now it is also risky for health, but it is also difficult to reduce it." (Participant $6, P$ )

\subsubsection{Trust barrier}

Next is the belief in obstacles, namely because of friends' invitations, then boredom, excitement when playing games, and the existence of free time. When playing games, they cannot control themselves, and also some online games played by participants have become a trend in electronic sports. In addition, the factor that becomes an obstacle is the existence of a quota or wifi, then only focuses on the game because it is chasing targets, and it is also difficult to change habits because it is fun to play. The participants continued to play even though they were feeling pain because they wanted to play very much and felt tempted to play games when they saw other people playing games, and when playing games, they forgot everything.

"The obstacles are like being bored, confused about what to do with playing the game again, besides that because there is an invitation from a friend." (Participant 1, G)

"Yes, because they cannot control themselves." (Participant 1, G)

"The thing that affects me to play games is there is no activity, then I live in a place with an average environment where people play games, so later friends come, let's play games, later friends come back, let's play games, so I'm forced to have to play like that."(Participant 2, S)

"Yes, playing together, especially if playing the game itself is not fun, the fun is not enough." (Participant 2, S)

"It's getting more fun because PUBG has become an e-sport, it's getting busier now." (Participant $2, S)$

"I don't know, and maybe it was before, I want to catch up, right in the game there is a level." (Participant 2, S)

"If you can say you can't control it, bro, because it's fun, bro, so I'm confused, but I want to try again, for example, in a day, I reduce it, five hours three hours, I wanna try, but I don't know how to do it, bro." (Participant 2, S)

"Yes, credit, no credit, no quota, you can't play games, bro. Apart from that, other factors are also the environment, there are friends." (Participant $3, P$ )

"Just exciting, bro, just exciting." (Participant 3, P)

"Yes, e-sport, because it's booming." (Participant 3, P)

"Yes, I want to change, but I can't, bro." (Participant 3, P)

"Hm, it's hard to say, because the control is difficult because most of these friends like games." (Participant 4, F)

"Besides, maybe this too, as long as there is free time, feeling bored, finally running to the game." (Participant 4, F)

"I want to change, and it's just that in an environment like this, it's a bit difficult to change, especially if all my friends in my neighbourhood are game lovers." (Participant 4, F)

"If people are used to playing games, it feels like something is missing if we don't play games, it's like eating vegetables without salt." (Participant 4, F)

"Usually I need rest, if it's not too heavy, for example, the head is a bit dizzy, I will continue, but if you feel a little tired, I will rest." (Participant 4, F)

"Maybe the environment can, then friends around who usually like to play games can also, what else, can it be from the environment, for example, there is smooth wifi so that they can play full." (Participant 5, D)

"The obstacle may be because of the fun playing the game, that's what prevents me from limiting when I want to reduce my playing limit." (Participant 5, D)

"Yes, because my friends also play games, every time, for example, I hear the sound of a game, it rings, I immediately bring my cellphone to play the game too." (Participant 5, D)

"Yes, there is no work, I will play the game, okay?." (Participant 6, P)

"If I chase, on mobile legends I chase rank." (Participant 6, P)

"It depends, but yes, for example, if I win, I am very satisfied, yes, but if I lose, I am not satisfied, so I play again until I win." (Participant 6, P) 


\subsubsection{Stimulus to action}

There is a stimulus to act on all participants, namely, disturbed sleep patterns, having friends who have dropped out of college, and being seriously ill. Besides that, it also disturbs concentration and has a fear of habits that are often done now.

"Yes, because of lack of sleep." (Participant 1, G)

"In my opinion, rest is important because if you don't get enough rest, there are impacts, headaches, insomnia, and ulcers." (Participant 2, S)

"That's my principle, bro if I play games until dawn, and in the morning there is a lecture, I still have to force myself to go to college, because my principles are like that, but there are cases like my friend who really likes playing Dota 2 on the computer, it wasn't until college. Finished" (Participant 3, $P$ )

"Yes, I want to, I never sleep-deprived, usually I sleep at six in the morning, sometimes I wake up at one or two in the afternoon, it's not less, but I want to sleep like a normal human, at ten, it's already asleep." (Participant 3, P)

"If there is an effect, it stops." (Participant 4, F)

"This is important, bro." (Participant 5, D)

"Yes, don't stay up late, and forget everything." (Participant 5, D)

"I was scared, but because I'm used to it, so okay, the important thing is I level up, like that." (Participant 6, P)

"It's me. I've already had my point of triumph in the mobile legend until dawn, then I take a break." (Participant 6, P)

\subsubsection{Self efficacy}

All participants believe to seriously want to change habits and keep trying and have faith. However, some participants do not know how to change habits.

"Yes, seriously." (Participant 1, G)

"Yes, very sure." (Participant 1, G)

"Yes, I'm serious, but I don't know how." (Participant 2, S)

"Yes, I want to change, but I can't, bro." (Participant 3, P)

"I want to be serious, but my friends, all of whom are game players, find it difficult." (Participant

$4, F)$

"Yes, seriously, mas." (Participant 5, D)

"But I will still try." (Participant 5, D)

"Yes." (Participant 6, P)

"But it is very difficult to reduce it." (Participant 6, P)

\subsection{Health impact on participants}

All participants experienced fatigue, sore and sore eyes, then dizziness, firefly eyes, decreased visual acuity, heartburn, chills, the risk of developing ulcers, and the risk of developing urinary tract infections. Sometimes feeling anxious and emotional and have a game addiction. Social relations become disturbed with people who do not play games because they often focus only on the game and good social relations. Because playing educational games becomes distracted, although not all experience it. Some participants prioritize education and think that games with education must be balanced.

"It can also damage health, fatigue." (Participant 1, G)

"Once, I had a headache, had back pain." (Participant 1, G)

"Yes, sometimes the eyes start to hurt, but they are forced to play." (Participant 1, G)

"Yes, I often delay eating and drinking while playing games." (Participant 1, G)

"Yes, you can get infections like that." (Participant 1, G)

"Yes, sometimes bro, when you think about something." (Participant 1, G)

"Oh yeah tired, yeah, because usually, we play up late, bro, so staying up late doesn't sleep at night, so it's like sore hands, especially moving wrists and fingers, and tired eyes." (Participant 2, S)

"Oh, if you know, because I also have heartburn, bro." (Participant 2, S)

"Yes, often bro, usually red like that, it usually hurts, then usually wash it again, and if the pain can't be tolerated, then I take a break and then continue again." (Participant 2, S) 
"Yes, bro, so far I have also been wearing glasses because of the influence of this game before I didn't wear glasses, maybe because I often play games so my eyes are damaged, and if I want to sleep, I feel dizzy like that." (Participant 2, S)

"This is how we usually get urinary tract infections." (Participant 2, S)

"Yes, sometimes sudden emotions." (Participant 2, S)

"If you don't play games, there is usually anxiety." (Participant 2, S)

"Tired is certain, for example I am dizzy, my body is weak, then lie down, so while lying down I watch YouTube, I watch heroes that I use in a game, so I want to try them in my game." (Participant $3, P)$

"Most obvious dizziness." (Participant 3, F)

"Yes, almost every day I play the game. When I play that game if you want to pee, wait until you really can't stand it, and then pee." (Participant 3, P)

"Oh, for example, if you are detained for a long time, you will get sick because it is full and you have not been expelled." (Participant 3, P)

"Yes, have a urinary tract infection." (Participant $3, P$ )

"Yes, yes, if you delay eating because, in the middle of the game, you are fun to play the game, you are hungry, you are arrested first, you delay eating first." (Participant 3, P)

"Often ulcers just like that." (Participant 3, P)

"Often watery, if over time it hurts the eyes." (Participant 3, P)

"In my daily life, sometimes if there is a trigger from outside, but I can still be held back a little." (Participant 3, P)

"Oh yeah, the body feels tired, tired." (Participant 4, F)

"Often, it usually delays eating." (Participant 4, F)

"Similar to heartburn, usually if I play games for too long, my eyes sting, and my head hurts too." (Participant 4, F)

"After playing the game, I usually feel that playing too long is dizzy." (Participant 4, F)

"Know a little the danger, and if you hear from a healthy person, it is usually the cause of urinary tract disorders."

"Such an infection." (Participant 4, F)

"Sometimes I get emotional while playing games, for example, I lose, that's definitely my emotions." (Participant 4, F)

"Oh, for that I usually get tired, sometimes tired, but usually I keep playing the game." (Participant $5, D)$

"Sometimes dizzy, sometimes the body feels chills, now a bit dizzy." (Participant 5, D)

"Yes, I get sick sometimes." (Participant 5, D)

"Sometimes you forget, bro, if you are fun playing games, that's why you have to eat now, forget about it, delay, a delay like that." (participant 5, D)

"Yes, maybe it's just an ulcer." (Participant 5, D)

"Oh yes, that's for sure, bro, because when I play the game, it usually takes a long time, not just an hour, so if you pee, you don't usually feel it, even if you want to pee, it's usually postponed first." (Participant 5, D)

"Yes, maybe later if we get used to it, there will be disturbances in our urine." (Participant 5, D)

"Oh, sure. If you play toxic games, you will come out." (Participant 5, D)

"Just a little bit." (Participant 5, D)

"Yes, definitely tired." (Participant 6, P)

"For myself, I often feel dizzy." (Participant 6, P)

"Yes, there are stinging eyes and fireflies for sure." (Participant 6, P)

"It's often late to eat." (Participant 6, P)

"Everything is postponed." (Participant 6, P)

"Resulting in ulcer disease." (Participant 6, P)

"I was having fun playing, and suddenly I wanted to pee so that it would be postponed." (Participant 6, P)

"Yes, you can pee stones later." (Participant 6, P)

"Yes, when I play games, I usually lose my temper." (Participant 6, P)

\section{DISCUSSION}

Based on the results of the research above, it was found that the participants experienced addiction in the high category of as many as six people, game addiction, namely excessive game use. The same study 
results found that internet gaming disruption is a condition of individuals who play games repeatedly and continuously [25]. All participants have played the game for more than six months which means that all participants can be categorized as game addiction, addiction occurs if a person meets the specified criteria within twelve months [26]. Then all participants played games a day for more than three hours. The hallmark of online game addiction is playing games more than three hours a day [6].

Overall, the participants were male, based on results of the study, there is a study which states that male participants experience game addiction by (97\%) [27], the same result is that men dominate playing online games (95\%) [28], then there are research results that stated that women make up half of the gamer population [29]. Based on this study's results, it is proven that the more men who play online games, this can be evidence that the level of game addiction in the male gender is higher than the female gender [30].

The six participants' age is in the late adolescence category, namely 21-24 years. Adolescents are divided into two parts, namely early adolescence and late adolescence. There are studies showing that online game addiction is more common in adolescents [31], [32]. Chen et al. [30] argued that adolescents and adult men found the use of internet games to be much more addicting. Overall the participants in this study were students who experienced game addiction, this is supported by the research of Efendy and Marnely [33], it was found that game addiction will have a negative impact on health, social, and student education. Ghuman and Griffiths [34] said that playing games have a bad impact, one of which is on health. Then Novrialdy [35] suggested that online game addiction can have a negative impact on adolescents. Based on the results of the study, it is known that participants who like to play games and often experience game addiction are at risk of experiencing negative impacts.

All participants live in a boarding house and rented, which makes participants free to play games for a long time because they are far from family. When playing games, participants often cannot control themselves, causing them to experience bad health effects. Overall, participants experienced health effects such as fatigue because participants often played games and lost track of time, even played games late at night, this is in accordance with Maulida and Sari's [36] research, that there is a relationship between internet addiction and sleep patterns, then the results of Fitria's [37] study also mentioned that there is a relationship between the duration of playing online games with disturbed sleep patterns. The results of this study concluded that playing games for a long time made the participants experience changes in sleep patterns so that they slept less than eight hours. A study also states that adolescents who are addicted to online games have weak immune systems due to lack of physical activity, lack of sleep, and frequent meals late [38]. The results of this study are in line with previous research described above, that male sex is the largest population who experience addiction, then adolescents and early adults are age categories that are vulnerable to online game addiction, and participants have the same habits such as staying up late due to addiction to play online game.

Then the participants also overall experienced eye pain due to prolonged viewing of the smartphone screen, this is in accordance with Muallima et al. [39] research, that there is a significant relationship between the distance variable using gadgets and a decrease in visual acuity. The same result was found in Santoso and Sundari's [40] study, that there is a significant relationship between playing online games and decreased visual acuity. According to the Ministry of Health of the Republic of Indonesia [41], eye fatigue is characterized by eye pain, soreness or itching, apart from watery eyes and sensitivity to light. Based on these results, it can be concluded that excessive smartphone use can be one of the causes of eye disorders. In addition, all participants also felt dizzy due to prolonged playing of games, this is in accordance with the research of Eijnden et al. [42] that the symptoms of gaming disorders have a negative impact on adolescents.

In addition, all participants often play games until they lose track of time so that which has an impact on health. Participants often delay eating and forget to eat so that they are at high risk of developing stomach ulcers. Research conducted by Sinanto and Djannah [15] found that the health effects that arise are changes in diet and lack of sleep, the same results were also found in the study of Susanti et al. [43] that there was a relationship between online games and diet. This study supports that playing games for a long time can impact health due to changes in diet, namely delaying eating and forgetting to eat because these habits will cause pain like ulcers.

All participants also frequently held back urination every time they played a game, this would put them at risk for urinary tract infections, Sari's [44] study, showed that there was a link between holding back urination and urinary tract infections. The results of these studies prove that the habit of the participants holding back urination often poses serious risks. Then the results of the research conducted by the researcher have in common with previous studies above that the participants experienced sore eyes, then decreased visual acuity, fatigue, dizziness, lack of sleep, the risk of developing ulcers, and the risk of experiencing urinary tract infections which could threaten the participants' health.

Then to change the behaviour of all participants who experience these health impacts, the importance of a health belief model in participants is so that they can behave healthily and avoid disease. 
Each participant has a health belief model in overcoming health problems, this health belief model describes the reason a person determines the method that is considered appropriate for him to prevent serious illness from his habit. Jose et al. [21] said that the health belief model shows a significant relationship with behaviour change.

Regarding susceptibility to experience pain, all participants felt vulnerable to disease. According to the construct of health belief theory, the vulnerability perception model is a person's beliefs about the risk of disease or health problems. Although all participants realized that they were prone to disease, all participants really liked playing games and cared about games because they had been playing games for more than six months. This is supported by a statement from the Ministry of Health of the Republic of Indonesia [45] that someone who is addicted to games will continue to play the game even though there are real negative consequences. In fact, playing games for more than six months is categorized as an addiction. This is what makes participants always play games even though they are aware that they are prone to disease. This is in accordance with the APA which states that a person is categorized as addicted if he has played games for more than twelve months [26]. According to the Ministry of Health [45], the results of this study are in line with the statement above that addicted online game players do not realize that they are experiencing addiction.

Then for the severity or belief in the negative impact, namely a person's subjective assessment of the severity of a health problem and the potential consequences if it is not prevented or treated. Participants are overall aware of the dangers of staying up late. These results are in line with Fitria's [37] research, which shows a relationship between the length of playing games with disturbed sleep patterns, based on the results found by researchers that participants often stay up late and prove that they have a risk of disease. Maulida and Sari's [36] research also found the same thing: a relationship between internet addiction and sleep patterns. Nursyifa, Widianti, and Herliani's [46] research found that respondents who were addicted to games mostly experienced sleep disorders. Regarding the habit of staying up late, of course, there is a risk of anaemia, this is in line with the research of Mawo et al. [13] which states that there is a significant relationship between sleep quality and haemoglobin levels in students. This study's results are in line with some of the previous studies above, that participants are at risk of experiencing negative health impacts because they often stay up late to play games.

The results found that all participants were aware of the dangers of delaying eating, and participants also often experienced ulcers. Based on the results found, this researcher has similarities with Susanti et al. [43] that there is a relationship between game addiction and diet, which indicates that the habit of delaying eating causes the disease experienced by participants, namely ulcers. The results of the research by Angkow, Robot, and Onibala [47] stated that there is a significant relationship between eating regularity and the incidence of gastritis. Then the same results were found in the study of Juliani and Nurchayati [48], which found an association between eating frequency and the risk of developing gastritis in adolescents. Manniko, Billieux, and Kaariainen [38] stated that adolescents who are addicted to games tend to have weak immune systems, lack sleep, and often delay eating. All study participants also frequently experienced delays in urinating. According to Sari [44], there was a relationship between the habit of delaying urination and urinary tract infections. All participants also often experience back pain and dizziness due to playing games, this is in accordance with the research of Ghuman and Griffiths [34], that the game disorder has detrimental effects, one of which is for health. In this study, it was found in common with previous studies that the habit of delaying eating can have a negative impact on gastric health, besides that participants have a risk of experiencing urinary tract infections due to the habit of delaying urinating.

They are associated with the belief in benefits, namely one's assessment of the value of self-efficacy in carrying out healthy behaviours to reduce the disease's risk. The results obtained by the researchers were that all participants knew the benefits of reducing playing time and understood the importance of rest. Based on this study's results, it is in line with Syahran's [3] research that one of the problems of game addiction can be done by limiting the maximum playing time to one hour a day. The need for rest is very important, humans have five needs that must be met, one of which is physiological needs or the most basic needs such as sleep [11]. The results of this study are in line with previous studies above, that limiting playing time can reduce the risk of negative impacts due to game addiction.

Then barrier beliefs are subjective judgments that include a person's perception of barriers to changing behaviour. In this study, it was found that overall all participants experienced almost the same obstacles, namely the invitation to be friends, this is in accordance with Darmawan et al. [49] research that a person's behaviour cannot be separated from the influence of the people around him so that someone will get used to the behaviour. Then online games are often played excessively, which results in addiction that results in bad behavior [50]. In addition, teenagers who are addicted to online games tend to be interested in online games compared to other things [51]. 
Also, the obstacles faced are boredom and free time. Participants always play games, boredom can make someone stressed so that they divert their boredom by playing games, there is a study states that stress is a risk factor for experiencing online gaming disorders [52]. Then the excitement in playing games makes participants unable to control themselves until they lose track of time while playing games, this is influenced by the inability to control emotions in playing games [53], [54], and the existence of supporting factors that make participants play games, namely the existence of gadgets and the internet. This is in accordance with the results found by researchers that participants will play games if there is quota or wifi. Online games are digital games that use the internet network [55].

According to the Ministry of Health of the Republic of Indonesia [45], someone who plays online games aims to have fun, relieve stress, and fill spare time. Based on this description, it can be concluded that someone will play the game because there is free time, and someone who does not want to leave the game is a result of game addiction. What influences participants to play games, one of which is the desire to play and the trend of electronic sports that is currently growing rapidly, electronic sports or e-sports are increasingly in demand by participants because currently e-sports are categorized as a sport, according to the Indonesian Ministry of Youth and Sports [56]. Electronic sports are a new area in gaming culture, then become something popular among adolescents and early adults [57], online games have now become professionals and some games have become the choice of gamers for a career in the world of electronic sports [58], [59].

Then the next one is a stimulus to act, namely the stimulus needed to trigger the decision-making process so that healthy behaviour occurs, a stimulus to act according to Rosenstock in Murti [20], not only from outside such as mass media communications, health workers, information, and personal interactions but also from the inside like a symptom of a disease. According to this theory, this is in line with researchers' results that all participants experienced changes in sleep patterns and were afraid of experiencing severe pain that came from within the participants because they had experienced pain such as dizziness and fatigue. A study states that using excessive time to play games will interfere with everyday life [60]. Based on Na'ran and Ahmad's [61] research, it was found that the impact of using online games was one of detrimental to health.

Furthermore, about the participants' beliefs, namely about their ability to perform behaviour to produce certain performance achievements. The result is that all participants are confident and serious about changing their habits, according to the results found that the researchers can categorize the self-efficacy of all participants as good, there is a study that states that individuals who spend a lot of time playing games tend to have low self-efficacy [62]. Then there are some participants who find it difficult to change because they are used to habits that are often done. Edrizal's [63] research found that one of the effects that emerged was less attention to health conditions, Kuss [64], said that online game addiction can trigger changes in activity and structure in brain areas related to motivation, memory, and control, Then Bass [65], revealed that the habit of playing online games is accompanied by an increase in dopamine levels in the dorsal striatum, then the dopamine pathway is investigated and encourages motivation to want to play more. In addition, playing games can cause cognitive abilities and self-control to decline. This is in accordance with the results found by researchers that the participants did not care about the impact, and continued to do habits that were at risk of causing disease.

One of the obstacles to game addiction can be solved by limiting the time to play, which is a maximum of one hour a day. In addition, the current most common treatment for online game addiction is cognitive-behavioural therapy. Cognitive-behavioral therapy is an effective form of psychotherapy for the treatment of internet gaming disorder [66]. According to Goroll and Mulley [67], cognitive behavioural therapy is used as primary or adjunct therapy for various mental illnesses, basically cognitive behavioural therapy helps clients change behaviour by changing beliefs. Cognitive-behavioural therapy (CBT) shows greater support from empirical studies than any other intervention in game addiction management [68]. The results showed that of the 72 articles found, there were 23 articles that described cognitive behavioural therapy (CBT) as psychotherapy for online game addiction, and showed satisfactory traits [69]. Online game addiction treatment can use behavioural therapy, and someone who is addicted to games really needs to reduce their playing hours, then replace playing games with physical, extracurricular activities, then reading books, playing music, and being able to visit a psychiatrist for therapy. Right, so as to reduce the risk of health problems due to game addiction.

\section{CONCLUSION}

Based on the research, there were six participants who experienced addiction in the high category, all of whom were male, aged 21-24 years, worked as students and lived in rented houses and boarding houses. The health effects of game addiction that participants felt were dizziness, fatigue, distracted concentration, risk of developing ulcers, and risk of developing urinary tract infections. In addition, 
participants have habits that are at risk of disease, such as staying up late, delaying eating, and delaying urinating. The participants were aware that they were prone to disease, but all the participants really liked playing games.

Then for the overall severity, they were aware of the dangers of staying up late, the dangers of delaying eating and delaying urinating due to playing games, and related to the belief in the benefits of all participants knowing the benefits of reducing playing hours and understanding the importance of rest. Then overall, all participants had almost the same obstacles, namely inviting friends to play games, boredom, free time, excitement to play games, and being unable to control themselves, as well as the trend of electronic sports.

Then related to the stimulus to action, it was found that all participants experienced changes in sleep patterns, and were afraid of experiencing severe pain so they wanted to change. Then regarding beliefs, it was found that all participants were confident and serious about changing their habits, and there were some participants who found it difficult to change habits because they were used to it. Suggestions for participants to be able to maintain their health, and limit their playing hours to at least one hour a day so that their physical needs are met.

\section{ACKNOWLEDGEMENTS}

The author would like to thank the Head of the Ahmad Dahlan University Public Health Masters Study Program for his support in this research.

\section{REFERENCES}

[1] F. Indahtiningrum, "The relationship between video game addiction and stress in Surabaya university students," Univ. Surabaya Sci. J., vol. 2, no. 1, pp. 1-17, 2013.

[2] Y. Y. Ng, C. W. Khong, and H. Thwaites, "A Review of Affective Design towards Video Games," Procedia - Soc. Behav. Sci., vol. 51, pp. 687-691, 2012, doi: 10.1016/j.sbspro.2012.08.225.

[3] R. Syahran, "Online Game Addiction And Handling," J. Educ. Psychol. Couns. J. Educ. Psychol. Couns. Guid., vol. 1 , no. 1 , p. 84, 2015, doi: 10.26858/jpkk.v1i1.1537.

[4] D. N. Greenfield, "Treatment Considerations in Internet and Video Game Addiction: A Qualitative Discussion," Child Adolesc. Psychiatr. Clin. N. Am., vol. 27, no. 2, pp. 327-344, 2018, doi: 10.1016/j.chc.2017.11.007.

[5] F. K. Anggarani, "Internet Gaming Disorder: Psychopathology of Modern Culture," Psychol. Bull., vol. 23, no. 1, p. 1, 2015, doi: 10.22146/bpsi.10572.

[6] F. M. Laili and W. Nuryono, "Application of Family Counseling to Reduce Online Game Addiction in Class Viii Junior High School 21 Surabaya," J. BK, vol. 05, no. 01, pp. 65-72, 2015, [Online]. Available: https://jurnalmahasiswa.unesa.ac.id/index.php/jurnal-bk-unesa/article/view/10396.

[7] WHO, "Gaming Disorder," World Health Organisation, 2018. https://www.who.int/features/qa/gaming-disorder/en (accessed Mar. 20, 2020).

[8] APJII, "Laporan Survei Internet APJII 2019 - 2020," Indonesia Survey Center, 2020. https://apjii.or.id/survei (accessed Mar. 20, 2021).

[9] KOMINFO, "Indonesia Asia's Digital Technology Giant (In Indonesia: Indonesia Raksasa Teknologi Digital Asia)," 2015. https://kominfo.go.id/content/detail/6095/indonesia-raksasa-teknologi-digital-asia/0/sorotan_media

[10] Newzoo, "The Indonesian Gamer 2017," 2017. [Online]. Available: https://newzoo.com/insights/infographics/theindonesian-gamer-2017/

[11] S. Siti Muazaroh, "Human Needs in the Thought of Abraham Maslow (In Indonesia: Kebutuhan Manusia dalam Pemikiran Abraham Maslow)," Al-Mazahib, vol. 7, no. 1, pp. 17-33, 2019.

[12] M. X. Zhang and A. M. S. Wu, "Effects of smartphone addiction on sleep quality among Chinese university students: The mediating role of self-regulation and bedtime procrastination," Addict. Behav., vol. 111, 2020, doi: 10.1016/j.addbeh.2020.106552.

[13] P. R. Mawo, S. D. T. Rante, and I. N. Sasputra, "Relationship between Sleep Quality and Hemoglobin Levels in Undana Faculty of Medicine Students," Cendana Med. J., vol. 17, no. 2, pp. 158-163, 2019.

[14] I. Shiue, "Self and environmental exposures to drinking, smoking, gambling or video game addiction are associated with adult hypertension, heart and cerebrovascular diseases, allergy, self-rated health and happiness: Japanese General Social Survey, 2010," Int. J. Cardiol., vol. 181, pp. 403-412, 2015, doi: 10.1016/j.ijcard.2014.12.071.

[15] R. A. Sinanto and S. N. Djannah, "Dampak Kesehatan Kecanduan Permainan Pada Pemain Game Usia Muda: Tinjauan Sistematis (In Indonesia: Health Impact of Game Addiction on Young Gamers: A Systematic Review)," VISIKES, vol. 19, no. 2, pp. 410-419, 2020.

[16] H. Masya and D. A. Candra, "Factors Affecting Online Game Addiction Disorder Behavior In Class X Students at Madrasah Aliyah Al Furqon Prabumulih," Guid. Couns. J., vol. 03, no. 1, 2016, [Online]. Available: http://ejournal.radenintan.ac.id/index.php/konseli/article/view/575.

[17] A. G. Alshehri and A. M. A. S. Mohamed, "The Relationship Between Electronic Gaming and Health, Social Relationships, and Physical Activity Among Males in Saudi Arabia," Am. J. Mens. Health, vol. 13, no. 4, 2019, doi: $10.1177 / 1557988319873512$. 
[18] A. M. Rajab et al., "Gaming addiction and perceived stress among Saudi adolescents," Addict. Behav. Reports, vol. 11, no. January, 2020, doi: 10.1016/j.abrep.2020.100261.

[19] N. S. Hawi, M. Samaha, and M. D. Griffiths, "Internet gaming disorder in Lebanon: Relationships with age, sleep habits, and academic achievement," J. Behav. Addict., vol. 7, no. 1, pp. 70-78, 2018, doi: 10.1556/2006.7.2018.16.

[20] B. Murti, Promotion Theory and Health Behavior, Edisi 1. Karanganyar: Bintang Fajar Offset, 2018.

[21] R. Jose, M. Narendran, A. Bindu, N. Beevi, M. L, and P. V. Benny, "Public perception and preparedness for the pandemic COVID 19: A Health Belief Model approach," Clin. Epidemiol. Glob. Heal., no. June, pp. 1-6, 2020, doi: 10.1016/j.cegh.2020.06.009.

[22] P. Taymoori, Y. Molina, and D. Roshani, "Effects of a Randomized Controlled Trial to Increase Repeat Mammography Screening in Iranian Women," Cancer Nurs, pp. 288-296, 2015, doi: 10.1016/j.physbeh.2017.03.040.

[23] F. G. Bai, "Perbedaan Tingkat Kecanduan Game Online Pada Remaja Antargaya Pengasuhan," Sanata Dharma University, 2015.

[24] J. W. Creswell, Penelitian Kualitatif and Desain Riset: Memilih di Antara Lima Pendekatan, Edisi Ke-3. Yogyakarta: Pustaka Pelajar, 2015.

[25] W. Feng, D. E. Ramo, S. R. Chan, and J. A. Bourgeois, "Internet gaming disorder: Trends in prevalence 1998 2016," Addict. Behav., vol. 75, no. 2016, pp. 17-24, 2017, doi: 10.1016/j.addbeh.2017.06.010.

[26] APA, "Diagnostic and Statistical Manual of Mental Disorders," American Psyciatric Association, 2013. https://www.psychiatry.org/psychiatrists/practice/dsm.

[27] G. J. Hyun et al., "Risk factors associated with online game addiction: A hierarchical model," Comput. Human Behav., vol. 48, pp. 706-713, 2015, doi: 10.1016/j.chb.2015.02.008.

[28] E. Nagorsky and J. Wiemeyer, The structure of performance and training in esports, vol. 15, no. 8 August 2020. 2020.

[29] O. Lopez-Fernandez, A. Jess Williams, M. D. Griffiths, and D. J. Kuss, "Female gaming, gaming addiction, and the role of women within gaming culture: A narrative literature review," Front. Psychiatry, vol. 10, no. JULY, pp. 114, 2019, doi: 10.3389/fpsyt.2019.00454.

[30] K. H. Chen, J. L. Oliffe, and M. T. Kelly, "Internet Gaming Disorder: An Emergent Health Issue for Men," Am. J. Mens. Health, vol. 12, no. 4, pp. 1151-1159, 2018, doi: 10.1177/1557988318766950.

[31] J. E. Brand, S. Todhunter, and J. Jervis, "Digital Australia 2018 (DA18)," Bond University, 2017.

[32] C. J. Jordan and S. L. Andersen, "Sensitive periods of substance abuse: Early risk for the transition to dependence," Dev. Cogn. Neurosci., vol. 25, pp. 29-44, 2017, doi: 10.1016/j.den.2016.10.004.

[33] A. Efendi and R. Marnelly, "The Impact of Playstation Game (PS) Addiction among Riau University Students," Online J. Students Fac. Soc. Polit. Sci. Riau Univ., vol. 1, no. 2, pp. 1-15, 2014, doi: 10.1017/CBO9781107415324.004.

[34] D. Ghuman and M. D. Griffiths, "A Cross-Genre Study of Online Gaming: Player Demographics, Motivation for Play, and Social Interactions Among Players," Int. J. Cyber Behav. Psychol. Learn., vol. 2, no. 1, pp. 13-29, 2012, doi: 10.4018/ijcbpl.2012010102.

[35] E. Novrialdy, "Online Game Addiction in Adolescents: Impact and Prevention," Psychol. Bull., vol. 27, no. 2, 2019, doi: 10.22146/buletinpsikologi.47402.

[36] R. Maulida and H. Sari, "The Relationship of Internet Addiction and Sleep Patterns in Nursing Faculty Students," Student Sci. J. Fac. Nurs., vol. 2, no. 3, pp. 1-8, 2017, [Online]. Available: http://www.jim.unsyiah.ac.id/FKep/article/view/3866.

[37] R. Fitria, "Old Games Online Games Against Student Sleep Pattern Disorders," Real Nurs. J., vol. 2, no. 2, p. 72 , 2019, doi: 10.32883/rnj.v2i2.484.

[38] N. Männikkö, J. Billieux, and M. Kääriäinen, "Problematic digital gaming behavior and its relation to the psychological, social and physical health of Finnish adolescents and young adults," J. Behav. Addict., vol. 4, no. 4, pp. 281-288, 2015, doi: 10.1556/2006.4.2015.040.

[39] N. Muallima, A. Febriza, and R. K. Putri, "The Relationship between Gadget Use and a Sharp Decline in Unismuh Makasar Junior High School Students," Iqra Heal. Sci. J., vol. 7, pp. 79-85, 2019.

[40] N. Santosa and L. P. Sundari, "The relationship between the duration of playing online games with visual impairment in junior high school (SMP) children in Denpasar," $E$ - J. Med., vol. 7, no. 8, pp. 1-12, 2018.

[41] Kemenkes, "Like what are the symptoms of tired eyes that often occur?," Directorate General of Infection Prevention and Control, 2018. [Online]. Available: http://p2ptm.kemkes.go.id/infographic-p2ptm/gangguanindera/seperti-apa-saja-gejala-mata-lelah-yang-sering-terjadi

[42] R. Van Den Eijnden, I. Koning, S. Doornwaard, F. Van Gurp, and T. Ter Bogt, "The impact of heavy and disordered use of games and social media on adolescents' psychological, social, and school functioning," J. Behav. Addict., vol. 7, no. 3, pp. 697-706, 2018, doi: 10.1556/2006.7.2018.65.

[43] M. M. Susanti, W. U. Widodo, and D. I. Safitri, "Addiction Relationship Playing Online Games on Smartphones (Mobile Online Games) With the Diet of Elementary School Children Grades 5 and 6 in SD Negeri 4 Purwodadi," Light Shine Ners World, vol. 3, no. 2, 2018, doi: 10.35720/tscners.v3i2.122.

[44] R. P. Sari, "Urinary Tract Infection (UTI) and Risk Factors Affecting Female Employees at the University of Lampung Event Numbers Urinary Tract Infection (Uti) and Risk Factors that Affecting on Female Employees In University of Lampung," Majority, vol. 7, no. 3, pp. 115-120, 2018.

[45] Kemenkes, "Playing Online Game: Filling Free Time, Having Fun or Addiction," Healthy My Country, 2018. [Online]. https://sehatnegeriku.kemkes.go.id/baca/rilis-media/20180706/4726551/bermain-game-online-mengisiwaktu-luang-bersenang-senang-ketergantungan/ 
[46] F. I. Nursyifa, E. Widianti, and Y. K. Herliani, "Sleep Disorders Students of the Faculty of Nursing, Padjadjaran University Who Experienced Online Game Addiction,” J. Nurs., vol. VIII, no. 1, pp. 32-41, 2020.

[47] J. Angkow, F. Robot, and F. Onibala, "Factors Associated with Gastritis in the Work Area of the Manado City Shoulder Health Center," J. Nurs. UNSRAT, vol. 2, no. 2, 2014.

[48] F. Juliani and S. Nurchayati, "The Relationship between Diet and Gastritis Risk in Adolescents," JOM FKp, vol. Vol. 5 No., pp. 643-651, 2018.

[49] T. Darmawan, N. Nurwati, and A. S. Gutama, "The Effect of Peer Interaction on Juvenile Delinquency in Sman 1 Cicalengka, Cicalengka District, Bandung Regency,” Res. Community Serv. Proc., vol. 3, no. 1, pp. 1-4, 2016, doi: 10.24198/jppm.v3i1.13624.

[50] I. Dhamayanthie, "The impact of online games on the behavior of Akamigas Balongan students (In Indonesia: Dampak Game Online Terhadap Perilaku Mahasiswa Akamigas Balongan)," J. Rekayasa, Teknol. dan Sains, vol. 4, no. 1, pp. 13-15, 2020.

[51] N. Jannah, M. Mudjiran, and H. Nirwana, "The Relationship between Game Addiction and Student Motivation and Its Implications for Guidance and Counseling," Counselor, vol. 4, no. 4, p. 200, 2015, doi: 10.24036/02015446473$0-00$.

[52] S. Yu, S. Mao, and A. M. S. Wu, "The interplay among stress, frustration tolerance, mindfulness, and social support in Internet gaming disorder symptoms among Chinese working adults," Asia-Pacific Psychiatry, vol. 10, no. 4, pp. 1-5, 2018, doi: 10.1111/appy.12319.

[53] J. Y. Yen, Y. C. Yeh, P. W. Wang, T. L. Liu, Y. Y. Chen, and C. H. Ko, "Emotional regulation in young adults with internet gaming disorder," Int. J. Environ. Res. Public Health, vol. 15, no. 1, pp. 1-11, 2018, doi: 10.3390/ijerph15010030.

[54] A. G. Jorgenson, R. C. J. Hsiao, and C. F. Yen, "Internet Addiction and Other Behavioral Addictions," Child Adolesc. Psychiatr. Clin. N. Am., vol. 25, no. 3, pp. 509-520, 2016, doi: 10.1016/j.chc.2016.03.004.

[55] E. Adams, Fundamentals of Game Design, Third. New York: New Riders Publishing, 2013.

[56] F. Kurniawan, "E-Sport in the Current Sports Phenomenon E-Sport in the Current Sports Phenomenon," JORPRES (Achievement Sport. Journal), vol. 15, no. 2, pp. 61-66, 2019.

[57] F. Bányai, M. D. Griffiths, O. Király, and Z. Demetrovics, "The Psychology of Esports: A Systematic Literature Review,” J. Gambl. Stud., vol. 35, no. 2, pp. 351-365, 2019, doi: 10.1007/s10899-018-9763-1.

[58] K. A. Faust, J. F. Meyer, and M. D. Griffiths, "Competitive and professional gaming: Discussing potential benefits of scientific study," Int. J. Cyber Behav. Psychol. Learn., vol. 3, no. 1, pp. 67-77, 2013, doi: 10.4018/ijcbpl.2013010106.

[59] M. D. Griffiths, "The Psychosocial Impact of Professional Gambling, Professional Video Gaming \& ESports Events Typically Involve Professional Video,” Casino Gaming Int., no. January 2017, pp. 59-63, 2017.

[60] D. L. King and P. . H. Delfabbro, Internet Gaming Disorder: Theory, assesment, treatment and prevention. New York: Academic Press, 2018.

[61] S. Na'ran and M. R. . Ahmad, "The Impact of Online Games on Students at SMA Negeri 4 Tana Toraja," J. Sociol. Educ. Social. UNM, vol. 3, no. 2, pp. 136-142, 2016, [Online]. Available: http://ojs.unm.ac.id/sosialisasi/article/view/2376.

[62] S. J. Chung et al., "Self-Efficacy and Clinical Characteristics in Casual Gamers Compared to Excessive Gaming Users and Non-Gamers in Young Adults," J. Clin. Med., vol. 9, no. 9, p. 2720, 2020, doi: 10.3390/jcm9092720.

[63] Edrizal, "The Effect of Student Addiction on Online Games (Study of Students' Habits of Playing Online Games) at SMP N 3 Teluk Kuantan (In Indonesia: Pengaruh Kecanduan Siswa Terhadap Game Online (Studi Tentang Kebiasaan Siswa Bermainn Game Online) di SMP N 3 Teluk Kuantan)," J. PAJAR (Education Teaching), vol. 2, no. 6, p. 1001, 2018, doi: 10.33578/pjr.v2i6.6543.

[64] D. J. Kuss, "Internet gaming addiction: Current perspectives," Psychol. Res. Behav. Manag., vol. 6, pp. 125-137, 2013, doi: 10.2147/PRBM.S39476.

[65] P. F. Bass, "Gaming addiction: when going online goes off-kilter," Contemp. Pediatr., vol. 32, no. 11, 2015, Accessed: Feb. 19, 2021. [Online]. Available: https://go.gale.com/ps/anonymous?id.

[66] J. Han, Y. Seo, H. Hwang, S. M. Kim, and D. H. Han, "Efficacy of cognitive behavioural therapy for internet gaming disorder," Clin. Psychol. Psychother., vol. 27, no. 2, pp. 203-213, 2020, doi: 10.1002/cpp.2419.

[67] A. H. Goroll and A. G. Mulley, Primary Care Medicine :Office evaluation and Management of the Adult Patient, 7th ed. Philadelphia: PA : Wolters Kluwer Health, 2014.

[68] D. L. King et al., "Treatment of Internet gaming disorder: An international systematic review and CONSORT evaluation," Clin. Psychol. Rev., vol. 54, no. March, pp. 123-133, 2017, doi: 10.1016/j.cpr.2017.04.002.

[69] I. L. Lemos, C. N. De Abreu, and E. B. Sougey, "Dependência de internet e de jogos eletrônicos: Um enfoque cognitivo-comportamental," Rev. Psiquiatr. Clin., vol. 41, no. 3, pp. 82-88, 2014, doi: 10.1590/010160830000000016 . 